\title{
Plant Stand Density and Photosynthetic Activity of a Mid-season Potato Depending on Pre-plant Soil Treatment in the Middle CIS-Urals
}

\author{
A.A. Skryabin \\ Federal State Budgetary Educational Institution of Higher Education, Perm State Agrarian-Technological University \\ Email: andrej.skryabin.2018@list.ru
}

Received: 14th November 2019, Accepted: 04th December 2019, Published: 31st December 2019

\begin{abstract}
The article presents data on the yield of medium-ripe potato varieties depending on pre-planting soil treatment in different weather conditions. The research was carried out in a farm on sod-podzolic soil with low humus content, medium acid reaction of the medium, high phosphorus and potassium content. The aim of the research is to identify the methods of pre-planting soil treatment providing a yield of $30 \mathrm{t} / \mathrm{ha}$. the experiment was used depending on the variant: plowing with a plow; milling with a vertical mill; disking. Predecessor winter rye for green manure. The planting rate is 50 thousand tubers/ha, row spacing is $70 \mathrm{~cm}$. The aim of the research is the yield of $30 \mathrm{t} /$ ha of mediumripe potatoes, depending on the pre-planting treatment, on average for 3 years, was achieved only in the control variant with plowing. It is noted that in different weather conditions growing seasons milling and disking differently reacted to the yield of potatoes: in dry and hot, optimal year was better milling, and in hot-disking. To achieve the goal, an average potato variety needs to form 152 thousand stems/ha with a leaf area of 25.6 thousand $\mathrm{m} 2$, the net productivity of photosynthesis is almost the same in the variants of the experiment $21-23 \mathrm{~kg} / 1000 \mathrm{~m} 2 \times$ day / ha, the yield in the experiment was determined by the value of the photosynthetic potential, not its productivity.
\end{abstract}

Keywords

Potato, Yield, Pre-planting, Plant Stand Density, Leaf Area, Photosynthetic Potential, Net Photosynthetic Productivity.

\section{Introduction}

To obtain high, stable potato yields, a loose, well-aerated and easily heated soil with good ability to retain moisture in the root layer is required $[1,2,3,4]$. In the non-chernozem zone of the Russian Federation, pre-planting cultivation of soil for potatoes includes harrowing, plowing of winter fallow, and in some cases cultivation or disking [5]. In Europe, pre-planting treatment is carried out by a milling cultivator which creates a small-lumpy soil structure, which significantly improves the conditions for plant growth and development, as well as combine harvesting [6]. However, not all scientists believe that milling is better. Researchers V.P. Kovalev, E.V. Botianovskii [7] believes that preplanting with a mill, especially on low humus soils and with a large amount of rainfall is accompanied by a significant compaction of the soil in comparison with plowing. Other scientists $[8,9]$ believe that the best conditions are provided by plowing light-textured soils in spring, and by plowing heavy-textured soils in autumn, and by heavy disc harrowing in spring.

Thus, in different soil and climatic zones, different methods of preplanting tillage turn out to be the best. The introduction of the Western European technology of potato cultivation in the Middle Cis-Urals recommends replacing the spring crop with milling processing, which seeks confirmation empirically.

\section{Methods}

Scientific research was carried out in the farm of the Middle Cis-Urals in 2001-2003. The objective of the research is to identify soil pre-planting methods for potatoes, providing a yield of $30 \mathrm{t} / \mathrm{ha}$. The authors studied techniques preceding ridge tillage. A one-factor experiment was carried out on sod-podzolic light loamy soil with a low humus content of $2.2 \%$, a medium acid reaction (pHKLC - 5.0), a high content of phosphorus $(241 \mathrm{mg} / \mathrm{kg}$ ) and a high content of potassium $(172 \mathrm{mg} / \mathrm{kg})$. Experiment design: 1. plowing with a PLN plow - 3-35 to a depth of $18-20 \mathrm{~cm}$; 2. milling with KVF - 2.8 to a depth of $10-12 \mathrm{~cm}$; 3 . disking with BDT-3 to a depth of 10-12 cm. The allocation of plots is systematic, the total plot area is $56 \mathrm{~m}^{2}$, the accounting area is $35 \mathrm{~m}^{2}$, the length of the accounting plot is $25 \mathrm{~m}$, the width is $1.4 \mathrm{~m}$, the experiment was conducted in quadruplicate [10]. The agricultural technique in the experiment was typical for the Perm Territory, but differed in a predecessor - green manure (winter rye green manure). Fertilizers were applied in the norm of $\mathrm{N}_{122} \mathrm{P}_{133} \mathrm{~K}_{180} \mathrm{~kg} / \mathrm{ha}$. Potatoes were planted with a potato planter, with a planting rate of 50 thousand tubers/ha, the average weight of the planting tuber is $50-80 \mathrm{~g}$, the method of planting is wide-row, the planting plan is $70 \times 30 \mathrm{~cm}$. The object of study is mid-season potato - Lugovskoy, reproduction - elite. Harvesting was carried out with a potato digger after yellowing of the lower leaves, followed by manual selection. Weather conditions during the years of the experiments were contrasting. The conditions of 2001 and 2003 were dry and warm, which negatively affected the potato yield. The conditions of 2002 were moderately warm with sufficient rainfall, which was favorable for potato vegetation.

\section{Results \& Discussion}

The objective of the research of $30 \mathrm{t} / \mathrm{h}$ h yield of Lugovskoy mid-season potatoes for an average of 3 years was achieved only in the control variant with plowing (Table 1). 


\begin{tabular}{|c|c|c|c|c|}
\hline Variant & 2001 & 2002 & 2003 & Average for 3 years \\
\hline Plowing (control) & 32.7 & 31.8 & 29.1 & 31.2 \\
\hline Milling & 32.9 & 30.0 & 21.3 & 28.1 \\
\hline Disking & 23.3 & 26.9 & 27.7 & 26.0 \\
\hline $\mathrm{HCP}_{05}$ & 4.1 & 3.2 & 4.4 & 1.0 \\
\hline
\end{tabular}

Table 1: The Yield of Mid-season Potato Varieties Depending on Preplant Soil Treatment, t/ha

A significant decrease in productivity in comparison with the control occurred in milling and disking by 3.1 and 5.2 $\mathrm{t} / \mathrm{ha}$, respectively $\left(\mathrm{HCP}_{05}=1.0 \mathrm{t} / \mathrm{ha}\right)$. There was also a significant difference between milling and disking $-2.0 \mathrm{t} / \mathrm{ha}$. According to years of research, in different weather conditions of the growing season, the yield of mid-season potato varieties was also different. In warm and dry weather conditions, the potato yield of $30 \mathrm{t} / \mathrm{ha}$ was achieved in plowing and milling, while disking showed a significant decrease in yield by $9.4 \mathrm{t} / \mathrm{ha}\left(\mathrm{HCP}_{05}=4.1 \mathrm{t} / \mathrm{ha}\right)$ in comparison with the control. In the optimal weather conditions in 2002, the research objective was achieved in plowing and milling, while disking showed a significant decrease in yield by $4.9 \mathrm{t} / \mathrm{ha}\left(\mathrm{HCP}_{05}=3.2 \mathrm{t} / \mathrm{ha}\right)$ in comparison with the control. During the hot growing season of 2003, a yield of $29.1 \mathrm{t} / \mathrm{ha}$, close to $30 \mathrm{t} / \mathrm{ha}$, was achieved in the control variant with plowing. A significant decrease in yield by $7.8 \mathrm{t} / \mathrm{ha}\left(\mathrm{HCP}_{05}=4.4 \mathrm{t} / \mathrm{ha}\right)$ in comparison with the control was observed in milling, while disking and control variants showed the same results.

On average, over three years, the yield of $30 \mathrm{t} / \mathrm{ha}$ of mid-season potato varieties was achieved with the plant stand density of 152 thousand/ha (Table 2). Improvement in the plant stand density in milling to 154 thousand did not increase the yield of potatoes. According to years of research, the target of $30 \mathrm{t} / \mathrm{ha}$ in dry and warm 2001 was obtained with a plant stand density of 136-141 thousand/ha, in the optimum weather conditions of $2002-156-162$ thousand/ha, and in hot $2003-156$ thousand/ha.

\begin{tabular}{|l|c|c|c|}
\hline \multicolumn{1}{|c|}{ Variant } & $\begin{array}{c}\text { Number of plants } \\
\text { to harvest, thousand pcs/ha }\end{array}$ & $\begin{array}{c}\text { Number of stems, } \\
\text { pcs/plant }\end{array}$ & $\begin{array}{c}\text { Number of stems, } \\
\text { thousand pcs/ha }\end{array}$ \\
\hline Plowing (control) & 42.2 & 3.6 & 152 \\
\hline Milling & 41.7 & 3.7 & 154 \\
\hline Disking & 40.4 & 3.6 & 145 \\
\hline
\end{tabular}

Table 2: Plant Stand Density of Mid-season Potato Varieties Depending on Pre-plant Soil Treatment. Average for 2001-2003

On average, over three years of research, a mid-season potato variety formed a maximum leaf area of 25.4-25.6 thousand $\mathrm{m}^{2} /$ ha in the early flowering in pre-plant plowing and milling (Table 3 ).

\begin{tabular}{|l|c|c|c|c|}
\hline \multirow{2}{*}{ Variant } & \multicolumn{2}{|c|}{ Leaf surface area } & \multirow{2}{*}{$\begin{array}{c}\text { Photosynthetic } \\
\text { potential, } \\
\text { thousand } \mathrm{m}^{2} \times \text { days } \\
\text { /ha }\end{array}$} & $\begin{array}{c}\text { Net photosynthetic } \\
\text { productivity, } \\
\mathrm{kg} / 1000 \mathrm{~m}^{2} \times \\
\text { days } / \mathrm{ha}^{2}\end{array}$ \\
\hline Plowing & 5462 & 25.6 & 1440 & 23 \\
\hline Milling & 5383 & 25.4 & 1383 & 21 \\
\hline Disking & 4892 & 22.4 & 1235 & 22 \\
\hline
\end{tabular}

Table 3: Leaf Area, Photosynthetic Potential, Photosynthetic Productivity of Mid-Season Potato Varieties, Depending on Pre-plant Soil Treatment. Average for 2001-2003

In disking, the minimum leaf surface area was 22.4 thousand $\mathrm{m}^{2} /$ ha. In the same variant, the lowest yield was 23.3 $\mathrm{t} /$ ha (Table 1). The photosynthetic potential at the end of the growing season for plowing was 1440 thousand $\mathrm{m}^{2} \times$ day/ha. In the same variant, the highest yield was $31.2 \mathrm{t} / \mathrm{ha}$. In milling and disking, a yield of 26-28 t/ha was obtained with a photosynthetic potential of 1383-1235 thousand $\mathrm{m}^{2} \times$ day/ha. According to years of research, the lowest photosynthetic potential of the mid-season potato variety was also in the variants with the lowest yield. The net photosynthetic productivity in the variants with pre-plant treatment was almost the same $-21-23 \mathrm{~kg} / 1000 \mathrm{~m}^{2} \times \mathrm{day} / \mathrm{ha}$. With the same productivity, the photosynthetic potential in disking was the lowest in the experiment - 1235 thousand $\mathrm{m}^{2} \times$ day/ha (see Table 31 ). This means that the yield was determined by the value of the photosynthetic potential rather than by its productivity.

\section{Conclusion}

The objective of the research of $30 \mathrm{t} /$ ha yield of Lugovskoy mid-season potatoes for an average of 3 years was achieved only in the control variant with plowing. It was noted that during vegetation periods different in weather conditions, milling and disking reacted differently to potato productivity: milling was better in a dry and hot year, while disking was better in a hot year. To achieve the objective, a mid-season potato variety needs to form 152 thousand stems/ha with a leaf area of 25.6 thousand $\mathrm{m}^{2}$, while the net productivity of photosynthesis is almost the same for the experimental variants $21-23 \mathrm{~kg} / 1000 \mathrm{~m}^{2} \times$ day/ha, the yield in the experiment was determined by photosynthetic potential rather than its productivity. 


\section{References}

1. Makarets I.K. The crushing degree of the soil during treatment // Agriculture. - 1982. - No. 5. - P. 23.

2. Galliev R.K. How to prepare the soil before planting // Potatoes and vegetables. - 1988. - No. 2. - P. 13.

3. Pazarenko I.I. Milling improves physical properties // Potatoes and vegetables. - 1991. - No. 2. - P. 19.

4. The effect of different treatment systems and fertilizers on the fertility of sod-podzolic soil / M.A. Mazirov et al. // Agriculture. - 2018. - No. 2. - P. 33-36.

5. Litun B.P. Potato growing of foreign countries / B.P. Litun, A.I. Zamotaev. - M.: VO Agropromizdat, 1988. - 167 p.

6. Ivenin V.V. Influence of light gray forest soil treatment systems on potato productivity in the Nizhny Novgorod region / V.V. Ivenin, A.V. Ivenin, V.N. Bogomolov // Agricultural science of the Euro-North-East. - 2015. No. 1. - P. 53-59.

7. Kovalev V.P. Processing sandy loam soil for potatoes / V.P. Kovalev, E.V. Botianovskii // Siberian Bulletin of Agricultural Sciences. - Novosibirsk, 1983. - Issue. 5. - P. 181-188.

8. Scholz B. Uberlegungen zur Pti anzbereitung tuz Kartoffelen // Kartoffelbau. - 1984.-№ 2. - P. 35.

9. Pisarev B.A. Potatoes in Japan // Potatoes and vegetables. - 1977. - No. 8. - P. 7-8.

10. Dospekhov B.A. Methods of field experience - M.: Publishing house 'Alians', 2011. - 352 p. 